\title{
Analisis Teknik dan Ujı Kinerja Mesin Pelubang tanah untuk Resapan Air
}

Technical Analysis and Performance Tests Land Hole Machine for Watering Response

\author{
Wahyu K Sugandi, ${ }^{1)}$ Zaida $^{1)}$, Asep Yusuf ${ }^{1)}$ \\ 1) Fakultas Teknologi Industri Pertanian, Universitas Padjadjaran Bandung \\ Jl. Raya Bandung-Sumedang Km 21 Jatinangor \\ Email : sugandiwahyu@gmail.com
}

\begin{abstract}
ABSTRAK
Lubang resapan merupakan salah satu cara untuk dapat menanggulangi permasalahan kualitas dan kuantitas air. Namun pembuatan lubang resapan masih menggunakan alat manual dan kurang efektif. Hal ini karena dilakukan oleh dua orang dengan laju pemboran hanya 1,6 cm/menit. Untuk menangani hal ini Laboratorium Alat dan Mesin Pertanian UNPAD telah merancang bangun Mesin Pembuat Pelubang Tanah Untuk Resapan Air. Mesin yang telah dibuat belum memiliki spesifikasi teknis, sehingga perlu dilakukan analisis teknik dan uji kinerja untuk menetapkan spesifikasi teknis pada mesin tersebut. Metode penelitian yang digunakan adalah metode desain dan dilanjutkan dengan percobaan secara empiris, yaitu melakukan desain, perhitungan dan pengukuran terhadap komponen struktural dan kinerja mesin yang meliputi kekuatan rangka, lendutan, laju pemboran, kebutuhan konsumsi bahan bakar, tingkat kebisingan dan tingkat getaran. Berdasarkan evaluasi kelayakan teknis dan kinerja mesin diperoleh bahwa kekuatan rangka untuk menopang beban maksimal adalah $6.048 \mathrm{~N}$, lendutan pada rangka sebesar $0,038 \mathrm{~mm}$, dengan laju pemboran $5,5 \mathrm{~cm} /$ menit, kebutuhan konsumsi bahan bakar 0,16 liter/jam, tingkat kebisingan $87,32 \mathrm{~dB}$ dan getaran mesin sebesar $46,38 \mathrm{~mm} / \mathrm{s}$. Hasil uji kinerja mesin menunjukkan mesin berfungsi dengan baik, namun getaran yang terjadi masih belum memenuhi standar uji mesin.
\end{abstract}

Kata kunci : Pelubang Tanah, Resapan Air, Lubang Resapan

\begin{abstract}
Absorption holes is one of the ways to solve with problems of water quality and quantity. However, making of absorption holes used manual tools and less effective. Laboratory Equipment and Agricultural Machinery Padjadjaran University had designed a drilling soil for water infiltration. But the machines had no specifications, so we need to study an engineering analysis and test of machine performance. The method used design method and empirical experiments, there were measurement and calculation of structural components and engine performance. The results from the research were to support the load force $6048 \mathrm{~N}$, deflections was $0.038 \mathrm{~mm}$, the power requirement was $0.57 \mathrm{HP}$, drilling soil was $5,5 \mathrm{~cm} /$ minutes, the consumption of fuel was 0.15 liters / hour, the noise level was $87.32 \mathrm{~dB}$ and vibration machines by $46.38 \mathrm{~mm} / \mathrm{s}$. The engine performance test showed that the machine work properly, but it still had vibration that had no qualified to the standard of the test machine.
\end{abstract}

Keywords: Drilling soil, Water Absorption, Absorption hole

Diterima : 16 Maret 2017 ; Disetujui : 3 Mei 2017; Online Published : 26 Oktober 2017

DOI : 10.24198/jt.vol11n2.3 


\section{PENDAHULUAN}

Semua makhluk hidup di bumi memerlukan air terutama manusia untuk memenuhi kebutuhan hidup sehari-hari, juga untuk kebutuhan domestik, pertanian, industri dan lain-lain. Kondisi air semakin terancam keberadaannya baik dari segi kualitas maupun kuantitas, hal ini disebabkan oleh perkembangan kehidupan yang terus berlangsung menuntut terjadinya perubahan penggunaan daratan dari lahan terbuka hijau menjadi lahan pemukiman, sehingga lahan untuk meresapkan air ke dalam tanah akan semakin sempit. Kondisi ini memerlukan adanya penanganan yang khusus dan berkelanjutan sehingga air dapat tetap tersedia dan dipertahankan kualitas dan kuantitasnya.

Konservasi tanah dan air merupakan usaha-usaha yang dilakukan untuk menjaga dan meningkatkan produktivitas tanah, kuantitas air dan kualitas air. Apabila tingkat produktifitas tanah menurun terutama karena erosi, maka kualitas air terutama air sungai untuk irigasi dan keperluan manusia lain menjadi tercemar sehingga jumlah air bersih semakin berkurang. Penerapan teknik konservasi tanah dan air meliputi teknik vegetatif, kimiawi dan sipil teknis. Penerapan teknik vegetasi berupa tanaman vegetasi tetap, budidaya tanaman lorong dan lain-lain. Penerapan kimiawi berupa pemberian mulsa dan zat kimia lain. Penerapan sipil teknis berupa pembuatan bangunan dam pengendali, dam penahan, teras, saluran pembuangan air dan sumur resapan dan lubang resapan tanah (Arsyad S, 2006).

Lubang resapan merupakan kegiatan konservasi sipil teknis yang sudah banyak dilakukan dan diharapkan dapat menanggulangi permasalahan ketersediaan air dan banjir. Lubang resapan ini ditujukan untuk menggantikan peresap alami yang hilang atau berkurang akibat meluasnya lahan pembangunan yang menjadi kedap tertutup, dengan cara mendrainasekan sebagian aliran permukaan sebagai substitusi peresap alami yang terjadi sebelum dilakukan pembangunan. Tujuan lainnya yaitu diharapkan dapat memberi kesadaran kepada masyarakat pemilik akan fungsi dan manfaat bangunan peresap sehubungan dengan fungsi resapan (Arsyad S, 2006).

Pembuatan lubang resapan saat ini sudah cukup banyak dilakukan di kota-kota besar terutama lubang resapan biopori. Pembuatan lubang resapan biopori pada umumnya masih menggunakan alat manual seperti bor biopori manual. Alat manual ini masih terdapat beberapa kelemahan terutama dalam efesiensi waktu dan tenaga yang dikeluarkan. Berdasarkan hasil pengukuran laju pengeboran tanah adalah 1,6 cm/menit yang dilakukan oleh 2 orang. Untuk itu Laboratorium Alat dan Mesin Pertanian Universitas Padjadjaran telah merancang bangun mesin pelubang tanah untuk resapan air dengan sumber penggerak motor bakar berbahan bakar bensin dengan harapan dari segi waktu lebih cepat dan operator yang menggunakan cukup satu orang saja, namun mesin tersebut belum teruji secara keseluruhan dan belum memiliki spesifikasi teknik. Oleh karena itu perlu dilakukan penelitian mengenai analisis teknis dan uji kinerja pada mesin pelubang tanah untuk resapan air, sehingga didapatkan spesifikasi dan data kinerja dari mesin pelubang tanah.

\section{METODOLOGI PENELITIAN}

Penelitian ini mulai bulan September Desember 2015 dilaksanakan di Laboratorium Alat dan Mesin Pertanian dan Bengkel Produksi Fakultas Teknologi Industri Pertanian Universitas Padjadjaran, Jatinangor. Metode penelitian yang digunakan adalah metode desain yang dilanjutkan dengan percobaan secara empiris yaitu melakukan pengukuran, 
pengamatan dan perhitungan terhadap alat pelubang tanah kemudian menganalisis tingkat kelayakan mesin dengan membandingkan data hasil perhitungan dengan ukuran aktual. Selain itu juga dilakukan kinerja dari mesin tersebut. Adapun analisis teknik yang dilakukan adalah sebagai berikut :

\section{Analisis Kekuatan Rangka}

Rangka berfungsi sebagai penahan beban yang berada diatasnya dimana rangka tersebut akan mengalami defleksi dan lengkungan sebagai akibat dari beban yang ditopangnya. Rangka mesin merupakan penyangga atau kedudukan dari semua komponen mesin. Analisis rangka dihitung berdasarkan lendutan dan beban kritis yang diizinkan. Beban yang dapat ditopang oleh baris menggunakan Persamaan (Singer dkk,1995):

$$
\delta=\frac{P L^{3}}{48 E I}
$$

Keterangan :

$\delta \quad=$ lendutan yang diizinkan $(\mathrm{mm})$

$\mathrm{L} \quad=$ Panjang kolom baris $(\mathrm{mm})$

$\mathrm{P} \quad$ = Daya yang dibutuhkan motor penggerak (watt)

$\mathrm{E}=$ Modulus elastisitas rangka $(\mathrm{kg} / \mathrm{mm} 2)$

$\mathrm{I}=$ Momen inersia rangka $(\mathrm{mm} 4)$

Kemudian lendutan yang terjadi akibat dari beban yang ditopang oleh rangka dibandingkan dengan lendutan izin yaitu (Singer dkk,1995) :

$$
\delta_{\text {izin }}=\frac{1}{300} L_{1}
$$

Keterangan :

$\delta=$ lendutan yang diizinkan ( $\mathrm{mm}) ;$

$\mathrm{L}=$ Panjang kolom baris $(\mathrm{mm})$;

\section{Analisis Kekuatan Las}

Pengelasan adalah metode pengikat logam dengan leburan. Terdapat dua tipe utama las yaitu las temu dan las sudut.
Kekuatan las ini dapat menopang beban rangka jika kekuatan las temu lebih besar dari gaya yang bekerja pada rangka (Singer dkk, 1995). Kekuatan las dapat dihitung menggunakan persamaan berikut ini (Shigley, 1986):

$F=\sigma \times h \times l$

Keterangan :

$$
\begin{aligned}
& \sigma=\text { Tegangan izin }\left(\mathrm{N} / \mathrm{m}^{2}\right) \\
& \mathrm{h}=\text { Tebal bidang las }(\mathrm{m}) \\
& \mathrm{I}=\text { Panjang bidang las }(\mathrm{m}) \\
& \mathrm{F}=\text { Gaya yang bekerja pada rangka }(\mathrm{N}) ;
\end{aligned}
$$

Tabel 1. Beban-Beban dari Komponen Mesin Pelubang Tanah Untuk Resapan Air Yang Ditopang Sambungan Las pada Rangka Utama

\begin{tabular}{cc}
\hline Komponen & Massa \\
\hline Motor Bakar + Bor & $18,5 \mathrm{~kg}$ \\
4 Bearing & $9,2 \mathrm{~kg}$ \\
2 Rantai & $4 \mathrm{~kg}$ \\
4 Gear & $6 \mathrm{~kg}$ \\
Bensin 1,5 Liter & $1,1 \mathrm{~kg}$ \\
\hline Total Gaya Aktual & $38,8 \mathrm{~kg}=380,498 \mathrm{~N}$ \\
\hline
\end{tabular}

Gaya yang ditopang oleh 1 sambungan las rangka utama :

$\mathrm{F}=\sigma \times \mathrm{h} \times \mathrm{I}$

$F=\left(21 \times 10^{6}\right) \times 0,002 \times 0,036$

$\mathrm{F}=1.512 \mathrm{~N}$

Gaya yang ditopang oleh 4 sambungan las (Gaya Teoritis) :

$\mathrm{F}=4 \times 1512 \mathrm{~N}$

$\mathrm{F}=6.048 \mathrm{~N}$

Tabel 2. Beban-Beban dari Komponen Mesin Pelubang Tanah Untuk Resapan Air yang Ditopang Sambungan Las pada Rangka Dudukan Motor Bakar

\begin{tabular}{|c|c|}
\hline Komponen & Massa \\
\hline Motor Bakar & $18, \mathrm{~kg}$ \\
\hline Bensin $1,5 \mathrm{~L}$ & $1,1 \mathrm{~kg}$ \\
\hline Total $(\mathrm{F})=$ Aktual & $19,1 \mathrm{~kg}=187,37 \mathrm{~N}$ \\
\hline
\end{tabular}


Gaya yang ditopang oleh 1 sambungan las pada rangka dudukan motor bakar :

$\mathrm{F}=\sigma \times \mathrm{h} \times \mathrm{I}$

$F=\left(21 \times 10^{6}\right) \times 0,002 \times 0,038$

$\mathrm{F}=1.596 \mathrm{~N}$

Gaya yang ditopang oleh 4 sambungan las (Gaya Teoritis):

$\mathrm{F}=4 \times 1596 \mathrm{~N}$

$\mathrm{F}=6.384 \mathrm{~N}$

\section{Kebutuhan Laju Pengeboran Tanah}

Pengukuran waktu pelubangan tanah dilakukan untuk mengetahui jumlah waktu yang dibutuhkan untuk membuat satu lubang tanah dengan kedalaman dan lebar yang ditentukan. Pengukuran waktu pelubang tanah ini menggunakan alat bantu stopwatch. Perhitungan waktu pengukuran menggunakan stopwatch dimulai pada saat mesin sudah menyala dan pada waktu mata bor mulai melubangi tanah sehingga didapatkan laju pengeboran.

Pengukuran waktu pelubangan tanah dilakukan dengan dua metode perhitungan waktu yang berbeda. Metode perhitungan waktu pertama yaitu stopwatch tidak dihentikan hingga kedalaman hasil pelubangan mencapai kedalaman yang diinginkan yaitu 50 $\mathrm{cm}$. Metode perhitungan waktu kedua yaitu stopwatch dihentikan ketika operator membersihkan tanah hasil pelubangan dan ketika mata bor tidak bekerja, hal ini karena kondisi tanah saat dilakukan pengujian ditemukan banyak bebatuan lalu perhitungan stopwatch dilanjutkan kembali ketika mata bor mulai melubangi tanah kembali. Kedua metode ini dilakukan agar didapatkan pengukuran waktu pelubangan tanah yang dapat menggambarkan kinerja mesin ini secara rinci. Setiap metode perhitungan dilakukan pengulangan sebanyak lima kali dengan setiap pengukuran disamakan kedalaman tanahnya yaitu dengan kedalaman $50 \mathrm{~cm}$.

\section{Konsumsi Bahan Bakar}

Pengukuran konsumsi bahan bakar dilakukan untuk mengetahui volume bahan bakar yang dikonsumsi oleh mesin untuk proses operasi per satuan waktu. Konsumsi bahan bakar dihitung dengan menggunakan persamaan:

$$
F C=\frac{F V}{t_{2}}
$$

Keterangan :

$$
\begin{aligned}
& \mathrm{FC}=\text { konsumsi bahan bakar (liter/jam) } \\
& \mathrm{FV}=\text { volume bahan bakar (liter) } \\
& \mathrm{t}_{2}=\text { waktu beroperasi motor penggerak } \\
& \text { (jam). }
\end{aligned}
$$

Pengukuran konsumsi bahan bakar ini menggunakan gelas ukur untuk menakar bensin dan oli dua tak yang akan dihitung. Setelah bensin dan oli dimasukkan kedalam tabung bensin pada motor bakar, mesin dinyalakan dan stopwatch dijalankan. Metode perhitungan konsumsi bahan bakar dilakukan sebanyak lima kali pengulangan, dimana setiap pengulangan dilakukan perhitungan waktu selama 20 menit menggunakan stopwatch. Pertama-tama bahan bakar bensin dicampurkan dengan oli dua tak pada gelas ukur, kemudian campuran bahan bakar tersebut dimasukkan kedalam tangki bahan bakar pada motor bakar lalu mesin dinyalakan. Setelah menit ke-20, mesin dan stopwatch dihentikan kemudian bensin yang ada didalam tabung bensin dikeluarkan dan dipindahkan ke gelas ukur. Setelah campuran bensin dipindahkan ke gelas ukur, jumlah bensin yang tersisa setelah 20 menit mesin dinyalakan diukur dan dicatat. Perlakuan ini dilakukan sebanyak lima kali pengulangan, sehingga didapatkan jumlah bensin yang dikonsumsi oleh mesin pelubang tanah untuk resapan air selama 60 menit atau 1 jam persatuan liter. 


\section{Tingkat Getaran dan Kebisingan Mesin Pelubang Tanah}

Alat yang digunakan untuk pengukuran kebisingan adalah soundlevel meter sedangkan untuk tingkat getaran adalah vibration meter. Adapun titik pengukuran mesin pelubang tanah yang akan diuji seperti tersaji pada Gambar 1.

Keterangan:

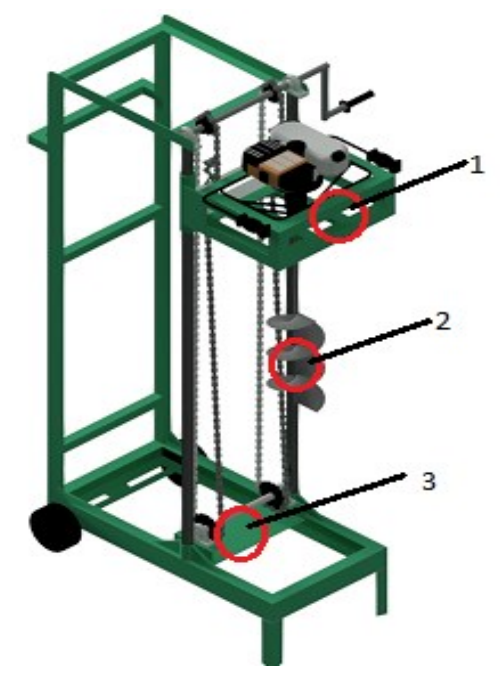

1) Rangka dudukan motor bakar

2) Ulir mata bor

3) Rangka utama mesin

Gambar 1. Rangka mesin pelubang tanah untuk resapan air

Pengukuran getaran pada mesin dilakukan menggunakan instrumen vibration meter. Pada mesin pelubang tanah untuk resapan air ini dilakukan tiga titik pengukuran yang dapat merepresentasikan getaran mesin secara keseluruhan, yaitu pada rangka dudukan motor bakar, rangka utama mesin dan ulir mata bor. Setiap titik pengukuran dilakukan lima kali pembacaan pada vibration meter lalu nilai tersebut dirata-ratakan dan didapatkan nilai getaran pada tiap titik pengukuran tersebut. Tiga titik ini merupakan sumber tingkat getaran tertinggi.

\section{HASIL DAN PEMBAHASAN}

\section{Kekuatan Rangka Mesin}

Mengacu pada analisis anthopometrik maka diperoleh dimensi keseluruhan mesin pelubang tanah untuk resapan air ini adalah 90 $\mathrm{cm} \times 41 \mathrm{~cm} \times 176 \mathrm{~cm}$ dengan rangka utama yang memiliki tinggi $7 \mathrm{~cm}$, lebar $41 \mathrm{~cm}$ dan panjang $80 \mathrm{~cm}$ serta rangka dudukan motor bakar yang memiliki tinggi $14 \mathrm{~cm}$, lebar $29 \mathrm{~cm}$ dan panjang $41 \mathrm{~cm}$. Rangka utama pada mesin pelubang tanah untuk resapan air ini menggunakan besi $U$ dengan ukuran besi $U$ 3, 6 $\mathrm{cm} \times 4,8 \mathrm{~cm} \times 36 \mathrm{~cm}$, dimana posisinya yaitu menahan beban motor bensin dan beban kolom, beban rantai dan sproket secara keseluruhan. Rangka dudukan motor bakar menggunakan besi siku dengan ukuran besi siku $3,8 \mathrm{~cm} \times 3,8 \mathrm{~cm}$.

Tabel 3. Data hasil perhitungan beban pada rangka

\begin{tabular}{cccc}
\hline $\begin{array}{c}\text { Bagian } \\
\text { Rangka }\end{array}$ & $\begin{array}{c}\text { Beban } \\
\text { Yang } \\
\text { Diterima }\end{array}$ & $\begin{array}{c}\text { Beban Izin } \\
\text { Maksimal }\end{array}$ & Keterangan \\
\hline $\begin{array}{c}\text { Rangka } \\
\text { Utama }\end{array}$ & $38 \mathrm{~kg}$ & $616 \mathrm{~kg}$ & Layak \\
\hline
\end{tabular}

\section{Berdasarkan perhitungan analisis} kekuatan rangka dengan menggunakan persamaan 1) dan persamaan 2) didapatkan beban maksimal yang dapat diterima mesin pelubang tanah untuk resapan air yaitu sebesar $616 \mathrm{~kg}$ (Tabel 3). Berdasarkan nilai beban maksimal tersebut, rangka utama pada mesin pelubang tanah untuk resapan air ini layak digunakan karena beban yang diterima mesin yaitu sebesar $38 \mathrm{~kg}$ ( motor bakar, bor, bearing, rantai, gear) 
Tabel 4. Data Hasil Perhitungan Lendutan Pada Rangka

\begin{tabular}{cccc}
\hline $\begin{array}{c}\text { Bagian } \\
\text { Rangka }\end{array}$ & $\begin{array}{c}\text { Lendutan } \\
\text { Yang } \\
\text { Terjadi }\end{array}$ & $\begin{array}{c}\text { Lendutan } \\
\text { Izin }\end{array}$ & Keterangan \\
\hline $\begin{array}{c}\text { Rangka } \\
\text { Utama }\end{array}$ & $0,038 \mathrm{~mm}$ & $1,36 \mathrm{~mm}$ & Layak \\
\hline
\end{tabular}

Perhitungan lendutan pada rangka utama mesin yang menggunakan besi kanal $U$ (Tabel 4) juga memenuhi kriteria atau layak untuk digunakan. Hal ini dikarenakan hasil perhitungan lendutan izin rangka yang terjadi pada rangka utama mesin yaitu sebesar 1,36 mm (persamaan 2), sedangkan nilai hasil perhitungan lendutan yang terjadi pada rangka yaitu sebesar 0,038 $\mathrm{mm}$ (persamaan 1). Berdasarkan data hasil perhitungan tersebut didapatkan kesimpulan bahwa lendutan yang terjadi pada rangka utama mesin pelubang tanah untuk resapan air ini masih berada dibawah batas izin lendutan dan rangka pada mesin pelubang tanah untuk resapan air ini layak untuk digunakan.

\section{Kekuatan Las}
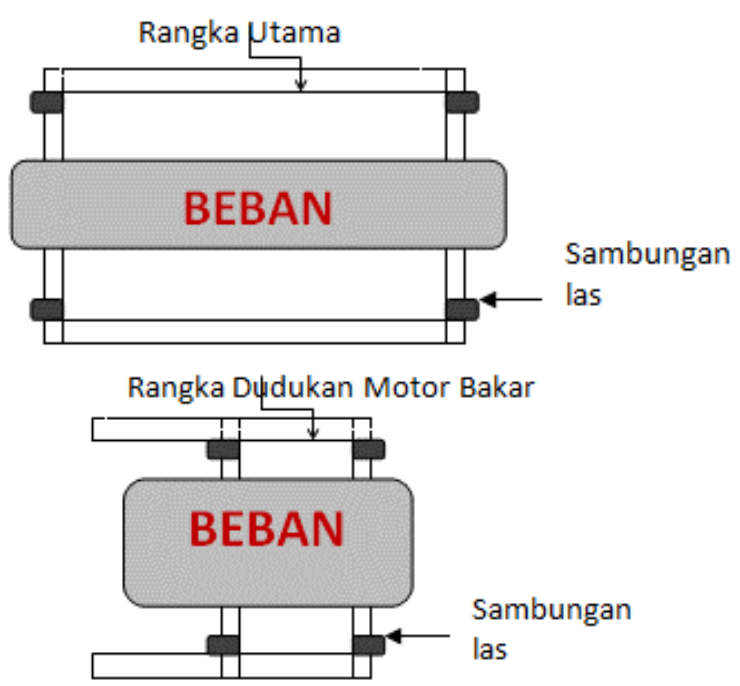

Gambar 2. Gambar Tampak Atas Bentuk Rangka Utama dan Dudukan Motor Bakar

Pada rangka utama mesin terdapat empat titik pengelasan (Gambar 2), yaitu pada ujung sambungan besi. Pengelasan pada ujung sambungan besi dilakukan agar besi dapat menyatu satu sama lain, dimana pada rangka utama mesin besi yang digunakan yaitu besi kanal U. Pada rangka dudukan motor bakar besi yang digunakan yaitu besi siku dan juga terdapat empat titik pengelasan. Pada rangka utama, beban yang ditopang oleh sambungan las yaitu sebesar $380,5 \mathrm{~N}$ atau $38,8 \mathrm{~kg}$ yang terdiri dari motor bakar, bor, empat buah bearing, 2 buah rantai, empat buah gear dan bensin 1,5 liter, sedangkan pada rangka dudukan motor bakar, beban yang ditopang oleh sambungan las yaitu sebesar 187,37 N atau $19,1 \mathrm{~kg}$ yang terdiri dari motor bakar, bor dan bensin 1,5 liter. Perbandingan kekuatan las secara aktual dengan perhitungan teoritis tersaji pada Tabel 5.

Tabel 5. Perbandingan kekuatan las secara aktual dengan perhitungan teoritis

\begin{tabular}{cccc}
\hline $\begin{array}{c}\text { Bagian } \\
\text { Rangka }\end{array}$ & F Aktual & F Teoritis & Keterangan \\
\hline $\begin{array}{c}\text { Rangka } \\
\text { Utama }\end{array}$ & $380,49 \mathrm{~N}$ & $6048 \mathrm{~N}$ & Aman \\
\hline $\begin{array}{c}\text { Rangka } \\
\text { Dudukan }\end{array}$ & $187,37 \mathrm{~N}$ & $6384 \mathrm{~N}$ & Aman \\
\hline
\end{tabular}

Perhitungan analisis kekuatan las menggunakan rumus gaya yang membutuhkan data ukuran rangka yang digunakan, tebal bidang las, panjang bidang las rangka utama dan dudukan motor bakar, tipe sambungan las dan tegangan izin las. Dengan perhitungan secara teoritis, didapatkan besarnya beban maksimal yang mampu ditopang oleh sambungan las pada rangka utama yaitu sebesar $6048 \mathrm{~N}$ atau $616,5 \mathrm{~kg}$. Beban maksimal $6048 \mathrm{~N}$ merupakan beban yang mampu ditopang oleh empat sambungan las, dimana tiap sambungan las mampu menahan beban 1512 N. Pada rangka dudukan motor bakar, beban maksimal yang mampu ditopang oleh sambungan las yaitu sebesar $6384 \mathrm{~N}$ atau 650,76 kg. Beban maksimal $6384 \mathrm{~N}$ merupakan 
beban yang mampu ditopang oleh empat sambungan las, dimana tiap sambungan las mampu menahan gaya 1596 N. Secara keseluruhan, beban yang diterima oleh sambungan las pada rangka utama maupun rangka dudukan motor bakar memiliki nilai yang lebih kecil dari beban maksimal yang diizinkan oleh sambungan las, sehingga sambungan las pada rangka mesin pelubang tanah untuk resapan air ini layak dan aman untuk dapat menopang beban yang diterima.

\section{Kebutuhan Laju Pengeboran Tanah}

Hasil pengukuran waktu pelubangan tanah metode pertama memiliki rata-rata waktu pelubangan 9 menit 13 detik dengan laju pengeboran tanah adalah $5,5 \mathrm{~cm} /$ menit. Waktu rata-rata ini bila dibandingkan dengan ratarata hasil pengukuran metode kedua yaitu 4 menit 46 detik dengan laju pengeboran 12, 5 $\mathrm{cm} /$ menit cukup berbeda jauh. Hal ini dikarenakan waktu operator membersihkan tanah hasil pelubangan tetap dihitung dalam perhitungan waktu keseluruhan metode pertama sehingga perbedaan waktunya cukup jauh. Perbedaan waktu yang hampir 5 menit ini dikarenakan cukup banyaknya bebatuan didalam tanah yang ketika dilakukan pengukuran menghambat laju mata bor untuk melubangi tanah, sehingga operator harus menaikkan atau memutar tuas sampai dengan posisi mata bor terangkat penuh lalu mengeluarkan bebatuan dan tanah hasil pelubangan. Hal ini dapat dilakukan berulang kali dalam satu pengukuran dikarenakan banyaknya bebatuan dan tanah hasil pelubangan, sehingga ketika batu dan tanah hasil pelubangan pertama telah dikeluarkan lalu pelubangan dilanjutkan kembali masih saja terdapat batu dan hasil pelubangan lainnya yang menghambat laju mata bor untuk melubangi tanah sampai dengan kedalaman 50 $\mathrm{cm}$. Seperti yang terlihat pada Gambar 3.

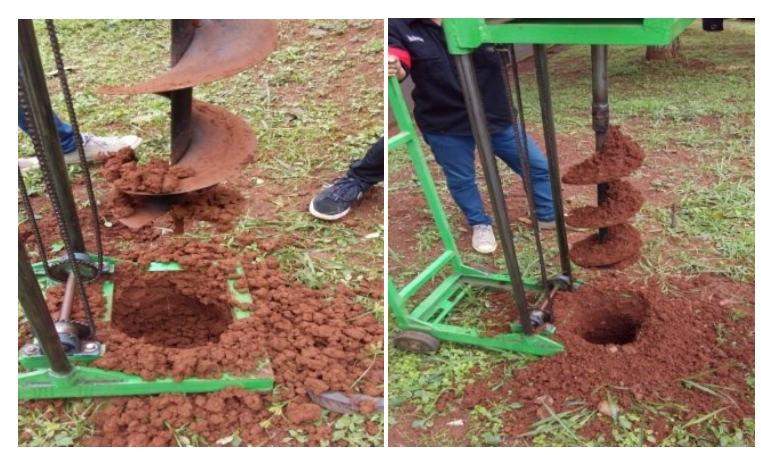

Gambar 3. Laju Pemboran Tanah

\section{Konsumsi Bahan Bakar}

Berdasarkan hasil pengukuran dan perhitungan didapatkan bahwa rata-rata konsumsi bahan bakar sebesar 0,16 liter/jam. Perhitungan konsumsi bahan bakar dilakukan dengan mencampurkan 0,2 liter bensin dan 0,04 liter oli dua tak pada gelas ukur.

\section{Tingkat Kebisingan}

Tingkat kebisingan diukur dengan menggunakan alat soundlevel meter dengan menempatkan alat pada jarak 2 meter dari sumber suara. Pengukuran tingkat kebisingan ini dilakukan sebanyak tiga kali dengan setiap pengukurannya dilakukan lima kali pembacaan. Hasil pengukuran kebisingan dapat dilihat pada Tabel 6 .

Tabel 6. Rata-rata tingkat kebisingan mesin saat tanpa beban dan dengan beban

\begin{tabular}{ccccc}
\hline \multicolumn{3}{c}{ Tingkat Kebisingan (dB) } & Syarat & Ketera \\
\cline { 1 - 3 } $\begin{array}{c}\text { Tanpa } \\
\text { Gas }\end{array}$ & $\begin{array}{c}\text { Gas } \\
\text { Setengah }\end{array}$ & $\begin{array}{c}\text { Gas } \\
\text { Penuh }\end{array}$ & $\begin{array}{c}\text { Uji } \\
\text { ngan }\end{array}$ \\
\hline 75,7 & 85,36 & 87,32 & $\begin{array}{c}<90 \\
\text { dBA }\end{array}$ & $\begin{array}{c}\text { Meme } \\
\text { nuhi }\end{array}$ \\
\hline
\end{tabular}

Berdasarkan hasil pengukuran (Tabel 6), didapatkan rata-rata tingkat kebisingan mesin saat gas pada motor bakar tidak ditekan yaitu sebesar $75,7 \mathrm{~dB}$, rata-rata tingkat kebisingan mesin saat gas pada motor bakar ditekan setengah sebesar $85,36 \mathrm{~dB}$, dan rata-rata tingkat kebisingan mesin saat gas pada motor bakar ditekan penuh sebesar $87,32 \mathrm{~dB}$ pada 
kecepatan putar 223 rpm. Dari data hasil pengukuran tersebut didapatkan bahwa tingkat kebisingan mesin yang tertinggi terjadi saat gas pada motor bakar ditekan penuh. Hal ini dikarenakan saat gas pada motor bakar di gas penuh menyebabkan getaran pada setiap komponen yang ada pada mesin terutama mata bor, sehingga menyebabkan bunyi yang lebih keras dibandingkan dengan pengukuran tanpa menekan gas ataupun menekan gas setengah. Nilai kebisingan mesin saat gas pada motor bakar ditekan penuh masih dibawah syarat uji yang diizinkan yaitu sebesar $90 \mathrm{~dB}$ atau masih dalam tahap aman, sehingga kebisingan yang terjadi tidak terlalu mengganggu operator saat mengoperasikan mesin dan tidak beresiko merusak pendengaran operator. Dengan rata-rata tingkat kebisingan maksimum mesin pelubang tanah untuk resapan air sebesar 87,32 dB, maka jam kerja yang diijinkan berdasarkan OSHA 1910,95 tidak melebihi 8 jam kerja/hari karena tingkat kebisingannya masih dibawah $90 \mathrm{~dB}$. Rata-rata tingkat kebisingan $87,32 \mathrm{~dB}$ dapat disamakan dengan bunyi peluit polisi dengan kondisi suara sangat hiruk pikuk. Salah satu solusi untuk menurunka tingkat kebisingan maka operator disarankan untuk menutup telinga dengan kapas atau benda lain yang bersifat lunak.

\section{Getaran Mekanik}

Berdasarkan hasil pengukuran pada saat motor digerakkan, rata-rata getaran mesin pada rangka dudukan motor bakar sebesar $33,68 \mathrm{~mm} / \mathrm{s}$, rata-rata getaran mesin pada rangka utama sebesar $20,96 \mathrm{~mm} / \mathrm{s}$, dan ratarata getaran mesin pada ulir mata bor sebesar $46,38 \mathrm{~mm} / \mathrm{s}$.

Hasil pengukuran pada ketiga titik pengukuran memiliki nilai getaran yang melebihi batas ambang yang dianjurkan dan masuk dalam tahap berbahaya untuk operator mengeoperasikan mesin, hal ini dikarenakan mata bor pelubang tanah letaknya jauh dari rangka dan tergantung sehingga menimbulkan getaran yang lebih besar dari getaran pada komponen-komponen lainnya. Mata bor merupakan faktor terbesar yang menghasilkan getaran, hal ini dikarenakan mata bor telah dimodifikasi dan ditambah ukuran panjangnya dengan menyambungkan mata bor dengan besi sepanjang $30 \mathrm{~cm}$ lalu dilas pada poros mata bor. Hal ini menyebabkan posisi mata bor yang tidak stabil dan mudah bergerak pada saat mesin dinyalakan yang menyebabkan getaran yang cukup besar.

Untuk getaran mesin pada rangka utama merupakan titik pengukuran yang terkecil dengan rata-rata $20,96 \mathrm{~mm} / \mathrm{s}$. Hal ini dikarenakan titik tersebut merupakan titik utama dari rangka dan komponen yang terdapat pada rangka utama ini hampir seluruhnya di las pada besi utama, sehingga getaran yang dihasilkan sangat kecil. Dari ketiga titik pengukuran getaran didapatkan rata-rata getaran yang terjadi pada mesin yaitu $33,67 \mathrm{~mm} / \mathrm{s}$. Nilai ini telah melebihi ambang batas yang diizinkan untuk mesin dengan daya kurang dari $15 \mathrm{~kW}$ yaitu $4,5 \mathrm{~mm} / \mathrm{s}$, sehingga getaran yang terjadi pada mesin termasuk dalam kategori berbahaya. Hal ini akan berdampak pada pada kerusakan mesin dan ketidaknyamanan si operator. Solusi untuk menurunkan tingkat getaran yaitu dengan memberikan karet peream pada alat rangka.

\section{KESIMPULAN DAN SARAN}

\section{Kesimpulan}

1) Kelayakan teknis dari mesin pelubang tanah untuk resapan air telah memenuhi syarat sehingga layak untuk digunakan dengan lendutan pada rangka hanya sebesar 0,038 $\mathrm{mm}$, kekuatan las untuk menopang beban $6048 \mathrm{~N}$ dan $6384 \mathrm{~N}$.

2) Tingkat kebisingan $75,7 \mathrm{~dB}$ tanpa gas, 85,36 $\mathrm{dB}$ gas setengah, $87,32 \mathrm{~dB}$ gas penuh, dan rata-rata getaran mesin sebesar $33,67 \mathrm{~mm} / \mathrm{s}$. 


\begin{abstract}
Dengan kebutuhan bahan bakar 0,16 liter/jam.

3) Hasil uji kinerja mesin menunjukkan bahwa mesin pelubang tanah untuk resapan air telah berfungsi dengan baik dengan laju pemboran $5,5 \mathrm{~cm} /$ menit.
\end{abstract}

\section{Saran}

1) Perlu diadakan modifikasi bor pelubang tanah sehingga getaran yang terjadi tidak terlalu besar. Dengan cara memasang karet peredam pada kaki mesin dan rangka dudukan mesin.

2) Perlu diadakan modifikasi pada rangka untuk menutupi bor sehingga lebih aman untuk digunakan operator.

3) Memasang karet peredam getaran pada kaki mesin dan rangka dudukan motor untuk mengurangi getaran yang terjadi pada mesin.

4) Perlu diadakan penelitian lanjutan untuk menentukan tingkat kenyamanan bagi operator dalam mengoperasikan mesin, terutama untuk rangka dan pegangan mesin.

\section{DAFTAR PUSTAKA}

Abdurrachman, Fabdullah. 2012 Uji kinerja mesin pelubang tanah untuk menanam sengon (Albizia falcataria L). Skripsi. Fakultas Teknologi Pertanian. Institut Pertanian Bogor. Bogor.

Arsyad S, 2006 Konservasi Tanah dan Air. IPB Press, Bogor.

Brata, Kamir R. dan Anne Nelistya. 2008 Lubang Resapan Biopori. Niaga Swadaya, Bogor.

Effendi. Telaah Kualitas Air Bagi Pengelolaan Sumberdaya dan Lingkungan Perairan. 2013 Kanisius: Yogyakarta .

Hall, A. S., A. R. Holowenko, H.G. Laughin. 1993 Theory and Problem of Machine Design.
McGraw-Hill Internasional Book Company, Singapore.

Hartono, Denny Rio.. 2012 Pengomposan sampah sisa buah-buahan dalam lubang resapan biopori di berbagai penggunaan lahan. Skripsi. Fakultas Pertanian. Institut Pertanian Bogor. Bogor

Irawan, A. P.. 2009 Diktat Elemen Mesin. Jurusan Teknik Mesin. Universitas Tarumanegara. Jakarta.

ISO 10816-1 : 1995 Mechanical Fibration Evaluation of Machine Vibration by Measurements on Non-rotating parts. International Organization for Standardization. Geneve. Switzerland.

Istigno, J. Hiegien. 1971. Keselamatan Kerja Terhadap suara dan Vibrasi. Perusahaan Keselamatan Kerja dan Jaminan Sosial.

Juliandari, Murti, Azwa Nirmala dan Erni Yuniarti. 2013. Efektivitas lubang resapan biopori terhadap laju resapan (Infiltrasi). Jurnal. Fakultas Teknik. Universitas Tanjungpura. Pontianak.

Lehto, M. R. and James, R. B 2008. Introduction to Human Factor and Ergonomics for Engineering. Lawrence Erlboum Associates, London. .

Pusat Pengkajian, Penelitian, dan Pengembangan Agribisnis (P4) dan BAPPEDA Jombang. 2011 Kajian teknis pembuatan lubang brokah (Biopori) pada lahan di kawasan kecamatan wonosalam. Fakultas Pertanian Darul 'Ulum Jombang. Jombang.

Sanders, M. S., and Cosmick, E. J. 1987..Human Factors in Engineering and design. Mc.Graw-Hill Book Co, Singapore

Shigley. J. E. 1986 Perancangan Teknik Mesin jilid 2.Edisi keempat. Erlangga, Jakarta..

Singer, F. L., Andrew, P. and Darwin, S. 1995. Kekuatan Bahan (Teori kokoh_strenght of Material). Edisi Ketiga. Erlangga, Jakarta. 
Sularso dan Kiyokasu, Suga. 1997. Dasar Perencanaan dan Perancangan Elemen Mesin. Cetakan Kesembilan. Pradnya Paramita, Jakarta. Sutalaksana, Anggawisastra dan Tjakraatmadja..
Teknik Tata Cara Kerja. Jurusan Teknik Industri ITB, Bandung.

Sutalaksana, Anggawisastra dan Tjakraatmadja. 2006. Teknik Tata Cara Kerja. Jurusan Teknik Industri ITB, Bandung. 